\title{
The Law Schools' Failing Grade on Federalism
}

\author{
Ben W. Heineman, Jr.†
}

Professor Cover's paper on federalism barely relates to the topic of the symposium-The Legacy of the New Deal: Problems. and Possibilities in the Administrative State-and this problem symbolizes a larger, more serious failure of the law schools.

The paper is court centered. But the main issues of federalism today are defined more by policy and politics than by judges. The question of what is desirable and feasible policy is vastly more important and more interesting than what is constitutionally permissible policy.

The paper is abstract and not grounded in economic and social fact. But federalism for what purposes and in what context: health, eduation, welfare, urban development, social services, racial equality, jobs and training, crime prevention, or mass transit?

The paper is ignorant of actual administrative structure and practice. An elaborate edifice of federal-state statutes, regulations, and custom has, of course, been erected in the past fifty years. Different areas-for example, health care, cash assistance, education-have very different histories and patterns of law and practice. But how these patterns have evolved-and how the Great Society altered the varied New Deal legacy (significantly in many instances relevant to federalism issues)-is not even mentioned, let alone described.

The paper is extremely weak in prescriptions that would be useful to a political executive, agency administrator, or legislator. A mayor or county manager, a welfare group or medical association director, a governor or president, a state legislator or committee chairman, would not find the piece of more than passing interest, if that. I have never understood why it is acceptable practice within the legal teaching profession to recommend relatively narrow doctrinal changes to courts, but not to take on the complex task of making more sweeping recommendations to legislatures. Surely it is not because the judicial process is somehow less political, more rational and more important than the legislative process. (Does any reader of this Comment seriously believe that ideas do not count in the legislative arena or that judges do not often render broad, "legislative" decisions by

† Mr. Heineman, a lawyer in Washington, D.C., was Assistant Secretary for Planning and Evaluation of the Department of Health, Education and Welfare during the Carter Administration. 
making value judgments first and justifying them later?) In any event, the paper reflects the dubious, if pervasive, professorial practice of giving legislative prescriptions short shrift.

The irony of these failings is that we are living in a period of great ferment about "federalism." It is, in fact, possible, though perhaps not likely, that a new public philosophy on the proper relationship between the federal and state governments will emerge in this decade to replace the New Deal-Great Society consensus. Recent national administrations have struggled unsuccessfully to give birth to a "new federalism," and the pressure for significant change, while yet unchanneled, remains strong.

This Comment discusses three ways of thinking about the possibilities of a new federalism consensus-in terms of policy conflicts, political conflicts, and functional analysis. A final section briefly suggests middle- or longer-term approaches to contemporary federalism.

\section{Policy Conflicts}

A new federalism consensus would respond to a host of problems that stem from the most significant legacy of the New Deal and its direct descendant, the Great Society-the vast increase in the tasks that the national government has undertaken, especially in the social welfare area, and usually with state and local governments. These problems may be expressed in terms of the following policy dilemmas.

(1) Coverage v. Cost. Despite the legislation of the past fifty years, tens of millions of Americans have incomes below poverty level, receive no or inadequate medical care, are provided substandard education, live in substandard housing, and cannot escape from "structural" unemployment. Yet to close these gaps in coverage would require tens of billions of dollars from federal, state, or local governments in an era of budgetary restraint.

(2) Universal v. Means-Tested Programs. In a period of constrained resources, it may be necessary to target funds more carefully on those with "need" rather than to increase expenditures for "universal" programs that benefit most citizens to some degree. The New Deal's major social welfare reform-Social Security - was a federal, "universal" program; the Great Society's major emphasis was on opportunity for the poor and near poor using a mix of federal, state, and local roles. But the policy impulse for better "targeting" of programs on those in need is countered by the administrative reality that to "means test" requires more bureaucrats and more "process."

(3) Comprehensive v. Incremental Change. Many policy analysts, noting the haphazard program growth in areas like income security or health care, suggest that comprehensive reform programs offer a more sensible policy approach. But for a variety of fiscal, administrative, and political 
reasons, incremental, albeit "messier," steps may be more feasible in the near term.

(4) Uniformity v. Pluralism. Many would argue that national programs meeting national needs should be uniform, but this approach conflicts with the nation's pluralist, federalism traditions. A commonplace compromise-joining federal-state financing and monitoring with state administration-has often led to the worst, not the best, of both worlds. Medicaid, for example, with its mix of federal-state financing and state administration, is generally regarded as one of the worst run social welfare programs, however laudable its goals.

(5) Efficiency v. Accountability. In the 1970's, Congress began to write overly detailed laws in an effort to limit executive branch discretion in the administration of social welfare programs in which state and local governments had a role. At the same time, the executive branch often issued excruciatingly detailed and burdensome regulations to control the exercise of state and local discretion in such areas as federal aid to education. Today, there is recognition that the tension between efficiency and accountability may have been resolved too far in favor of accountability.

A companion set of issues relates to whether the federal government should regulate the states by direct or indirect methods. Are block grants to the states and loose federal oversight preferable to narrow, categorical programs and more stringent federal oversight? To achieve state accountabilty to federal purposes, is it preferable to impose procedural requirements and financial penalties for poor performance or to establish substantive standards with financial rewards for good performance?

(6) State v. Local. The federalism debate is not just over whether governmental functions are best carried out at a federal or state level. Just as often, there are important questions about whether local rather than state government is better suited to finance, administer, or evaluate various programs.

(7) Theory v. Ignorance. The major federal-state programs are based on either explicit or implicit theories of change, since they are aimed at altering social or economic conditions. Yet, these theories are, in turn, based on social science, which, since the mid-1960's, has been subjected to substantial questioning and revision after being oversold to justify a program. Moreover, there is often confusion about actual effects that programs have or have not had-and even about how they have been administered. At all levels of government, those who would make changes in existing programs (either to contract or expand them) have to find an acceptable balance between perfect theories and knowledge (which will never exist) and no theories and grossly incomplete knowledge (which too often exist). 
(8) Demonstration v. National Programs. The "theory v. ignorance" dilemma often leads to the cry for demonstration programs to "test" untried ideas either under federal direction or at the states' own initiative. But the utility of social research and experimentation-and who should conduct it under what standards-is a subject of contentious debate. Moreover, actually carrying out such a demonstration takes years, and deciding who shall benefit from it until the results yield a decision on a national program is, to put it euphemistically, not easy.

(9) The Role of Government. Any debate about federalism will inevitably get caught up in the national debate about what levels of the Gross National Product should be devoted to government ${ }^{1}$ and what proportions should go to defense and domestic spending. But in thinking about "domestic" spending, we should look not just at the federal budget but at the combined budgets of all levels of government by function, and we should examine the taxing and spending histories of nations in Western Europe. Federalism issues also touch a major debate between direct, government administered programs and more indirect programs involving tax expenditures (credits, deductions) or vouchers. Finally, as new problems emerge, the argument without end about whether government has any role to play in addressing social problems or structures will be rekindled-for example, should government provide transitional payments or training to workers from "smokestack" industries who have permanently lost their jobs?

\section{Political Conflicts}

These conflicts in social welfare policy, which affect federal, state, and local governments, are mirrored in fundamental political conflicts, not just among political parties or between "liberals" and "conservatives," but among affected individuals. Anyone approaching the subject of federalism today will soon become deafened by the din from the following battles.

(1) Existing Recipients v. Future Recipients. The political impulse to "grandfather" existing recipients-that is, to protect their present level of benefits in any program change-is always strong, but it often undercuts the desire to make more "rational" for future recipients the spate of programs that may have grown up in an area. The problems of "grandfathering" may also significantly decrease the probability of enacting major reforms because carving out elaborate exceptions to reforms can impose significant administrative costs or prevent savings needed to finance such reforms.

(2) Young v. Old. It is a commonplace that we are now living in the

1. At present, this figure for federal, state, and local governments is about 33\%. J. PALMER \& I. SAWHILL, THE REAGAN EXPERIMENT 100 (1982). 
midst of a demographic phenomenon - the aging of America (and indeed the aging of the aging). Yet, with scarce government resources, the claims on the public fisc of programs for the aged are in sharp conflict with the claims of programs for the young - at all levels of government.

(3) Poor v. Middle Class. Similarly, the huge, inexorable growth of the non-means tested government "entitlement" programs that benefit the middle class-like Social Security and Medicare-has meant that funding for programs aimed just at poor people, especially "discretionary" programs (subject to the annual appropriations process), has been either cut or held level (that is, cut in real terms given inflation). This political conflict, like the tension between young and old, affects domestic programs (and planning) at all levels of government.

(4) Region v. Region. Regional conflict is as old as the Republic, and we are now in another period of intense sectional rivalry-this time concerning the equities of inter-state funding flows generated by federal taxing and spending policies. These issues of funding flows-how much, for example, do New York and Mississippi get back from the federal government for each federal tax dollar sent to Washington-are sharpened by, and partly cause, another demographic change currently underway: major population shifts from the Northeast and Midwest to the South and West.

(5) State v. Local. This conflict, while it often has a policy dimension, is also worthy of note as a fundamental political conflict at the core of any debate about federalism. Governors are always jousting with mayors and county executives for control of federal funds and "federalism" programs.

\section{A Functional Perspective}

In addition to exploring policy and political conflicts, a third way to think about contemporary federalism, and about the possibilities of a new federalism consensus, is functionally - a method of analysis that should be readily understood and applied in the law schools. This method looks at the range of programs where there is shared federal-state-local responsibility and asks:

First, who has the discretion to establish benefits-and what are they?

Second, who establishes the eligibility criteria for determining which citizens qualify for what benefits-and what are they?

Third, who finances the benefits-and by what method?

Fourth, who monitors, evaluates, and plans future changes in the programs?

Fifth, who actually administers these program functions, that is, who distributes benefits, actually determines eligibility, and collects and distributes funds within governments?

Only after obtaining this type of knowledge across types of programs 
can one begin the pressing job of sorting out which levels of government, if any, should perform which tasks today, and answering the crucial question of where the financial burden for which type of program should lie.

\section{Possibilities: Long Term-Middle Term}

Surely the complex of questions surrounding contemporary federalism is factually intriguing, conceptually challenging, and eminently worthy of sustained analysis by the law schools. For example, there is today a clear need to develop alternatives to the nation's current income security "system"-congeries of programs that are a mixed federal-state responsibility. These programs-broadly defined to include social insurance, needs-tested cash and in-kind transfers, public service employment, social service efforts and various tax expenditures-now constitute approximately half of the federal budget. ${ }^{2}$ Similarly, they constitute approximately twenty-eight percent of total state expenditures for $1981 .^{3}$ They have grown in an incremental fashion since 1935. Although they have individually, or in some combination, been the subject of numerous studies, an overview is needed.

(1) The interrelationships between the programs are not well understood, although many citizens benefit from a number of them. Thus changes in a particular program are often not considered with the effects on other programs clearly in view, in part because good information is not available.

(2) The cost of the programs has been rising rapidly, and the system must be seen as a whole to understand the significant cost implications for the future, and how these costs relate to the general growth of the economy, to our national economic health, and to the economic health of individual states.

(3) The adequacy of the programs for various groups within our society is also questionable-for example, the working poor may not qualify for important income-tested programs like Medicaid-and the gaps in coverage must be closed.

(4) There are substantial work disincentives within the total income security system, due in part to the overlap between the programs.

(5) The programs suffer from sharply divided jurisdictional responsibilities in the Congress, diffuse management responsibilities among a host of agencies and departments in the federal government, and confusing differ-

2. See U.S. GEN. ACCOUNTING OFFICE, COMPTROLLER GENERAL'S REPORT TO THE CONGRESS, U.S. INCOME SECURITY SYSTEM NEEDS LEADERSHIP, POLICY, AND EFFECTIVE MANAGEMENT 6 (1980).

3. This figure is derived from Census Bureau data cited in Table III of the executive summary of a January 24, 1983, research report ("The State of the States") prepared by the American Federation of State, County and Municipal Employees and the Public Employee Department, AFL-GIO. 
entiation of roles among federal, state, and local governments that vary, often without good reason, among similar programs.

(6) Variation among program features-eligibility, benefits, administrative procedures-confuses the public and contributes to waste and error in program administration.

(7) There are fundamental questions about such basic conceptual building blocks for the income security programs as poverty, disability, and unemployment, and, increasingly, old age and retirement.

An alternative to a comprehensive view of the broad array of social welfare programs that constitute the income security system would be an analysis of policies and prospects for "middle-term" change. For example, at the end of the 1970's, an executive-congressional-state-local consensus was beginning to emerge around the following changes. In health care, federalize Medicaid, develop joint administrative systems with Medicare, and try to find a larger role for the private sector in monitoring and accounting for flows of money within the programs. In elementary and secondary education, return more authority to the states: A host of federal categorical programs would be abolished and the federal government would be primarily responsible only for compensatory education to the poor and the handicapped through new incentive-based methods of holding the states accountable. In cash transfer programs, the universal programs, with their social insurance base, would, of course, remain federalized, but much greater attention would be paid to the relationship of these programs to the private pension system. The means-tested programs would be consolidated, would have a greater degree of uniformity, and would have a higher federally funded floor; methods by which the states could supplement those floors, however, would be simplified, and these means-tested cash assistance programs would be more closely integrated with a combination of private and public sector jobs programs for those who could work.

But whatever the direction, whether a long-term comprehensive approach or a middle-term, more incremental approach, the law schools should be much more directly and heavily involved than they are at present in this debate about federalism "possibilities." The issues of federalism are classic problems that deserve detailed law school attention. They are rich in history. They bristle with difficult administrative detail. They involve complex, interrelated financing mechanisms. They pose intriguing problems of making important choices in a state of irnperfect knowledge. And they raise fundamental choices about the kind of society we ought to be. But they have, in an analytic sense, largely been ignored, left to the economists, the think tanks, and the schools of public policy.

When I was at HEW, and deeply involved in these problems at both 
administrative and planning levels, I was overwhelmed with reading and briefings. But not once did I have occasion to look in the law journals, nor were law professors cited as authority (or ever mentioned) in briefings. Although we were dealing with nearly half of the federal budget on difficult issues that implicate every state and locality, the law schools seemed to have little to say.

I can only hope this will change and that people with great talent like Bob Cover will turn their energies to these issues. Constitutional history is important. But it is surely only one part of the needed analysis. And it does not take us very far along the path to answering legitimate and important questions about federalism: What is the legacy of the past fifty years, what are the problems left by that legacy and what are the possibilities for change. Seeking answers to those questions in the complex context that I have barely outlined is surely worthy of Professor Cover's effort-and of his colleagues in the schools of law. 